\title{
Higher education and the Sustainable Development Goals
}

\author{
Maia Chankseliani ${ }^{1}$ (D) Tristan McCowan ${ }^{2}$
}

Accepted: 30 October 2020 / Published online: 6 November 2020

(c) Springer Nature B.V. 2020

This special issue of Higher Education focuses on higher education and the Sustainable Development Goals (SDGs). The 17 SDGs adopted by all United Nations member states in 2015 cover a broad range of issues related to socio-economic, environmental and technological development, and apply to all of the world's countries, and not only those normally considered to be 'developing' or 'emerging'. As part of its broad remit, the SDGs expanded the focus beyond primary and secondary education to include tertiary education. This was an important move as higher education was missing from the international development agenda as evidenced by previous sets of development goals - the Millennium Development Goals and Education for All.

One of these goals-SDG 4-calls for equal access to tertiary education, including university, as part of the promotion of lifelong learning opportunities for all. Yet, universities have another important role in the SDGs, as a driver for the achievement of the full set of goals, through their role in human formation, knowledge production and innovation. This special issue builds on the existing scarce literature (Aarts et al. 2020; Castells 1994; McCowan 2016, 2019; Milton \& Barakat 2016; Neave et al. 2000; Owens 2017; Schendel \& McCowan 2015) to examine this latter, and less commonly discussed, role of higher education in addressing the SDGs.

University as an institution has a long history, starting as an educational establishment, later assuming the knowledge creating (research) function and more recently the so-called third mission (engagement). In most contexts, universities were for the elites, educating them for religious, professional or administrative occupations. With the expansion of higher education participation, university has acquired a larger potential for contributing to societal development. Teachers, doctors, engineers, among other professionals, obtain academic education at a higher level to practice their professions and support societies. Furthermore, universities undertake fundamental and applied research in sciences and humanities to improve our understanding of life.

There exist diverse exemplars of universities' innovative engagement with the global challenges, such as the University of Pretoria's (South Africa) strategy to use research for addressing societal problems across the continent, with a focus on food security. Another example is the Ahfad University for Women (Sudan) which provides a holistic experience through academic courses, research, on-the-job training and community extension activities

Maia Chankseliani

maia.chankseliani@education.ox.ac.uk

1 Department of Education 15 Norham Gardens, University of Oxford, Oxford, England

2 UCL Institute of Education, University College London, 20 Bedford Way, London, UK 
to support women as change agents and future leaders. These universities, together with 15 others, have been designated as SDG Hubs for their commitment to addressing SDGs and educating future generations about the biggest global challenges (United Nations 2018). The creation of the SDG Hubs within higher education institutions is an indication of the timeliness of strengthening our empirical and conceptual understanding of how SDGs can be achieved through higher education. Another confirmation is a recent attempt to measure universities' success in delivering the UN Sustainable Development Goals. The Times Higher Education (THE) University Impact Rankings, introduced in 2019 to measure institutions' social and economic impact, recognise more than 700 universities across the world for their work on tackling the biggest global challenges; these universities include the University of Auckland (New Zealand) for their research on the sustainable use of terrestrial ecosystems, the Tongji University (China) for their work on affordable and clean energy, the University of São Paulo (Brazil) for their work on ending poverty, amongst other institutions (THE 2020).

Nevertheless, while there are widespread initiatives of the type outlined above, and an increasing number of universities aligning their activities with the SDGs, there is a significant gap in knowledge and evidence. There is still a need to document the wide variety of activities relevant to sustainable development being undertaken by universities, particularly in low- and middle-income countries, and to assess the consonance between activities of teaching, research, community engagement and campus operations. Furthermore, rigorous research is needed to gauge the impact in practice of these activities on society, beyond the intentions or assumptions of the work. As a result, there exist a number of unanswered questions in terms of the institutional forms and practices that can best support the SDGs, and the influences of local and national contexts.

This gap of evidence and research is no small challenge, but there exists a further issue. The SDGs are not a problem-free, consensual package that universities can simply set their sights on and gather the political will and resources to achieve. Sustainable development is nested in a set of political, moral and epistemic assumptions that are not shared by all-in particular, Enlightenment notions of progress, and the continuing existence of global capitalism, albeit in a tempered and regulated form. On the other side of the political spectrum, there is denial of anthropogenic climate change and scepticism of the role of international organisations and agreements. In terms of the framework itself, while many of the goals are mutually reinforcing, there are inevitable tensions and trade-offs. There are also questions about the extent to which the university - at heart an institution oriented towards the development of knowledge and understanding — can and should be held to such practical and immediate impacts on the world around.

'International development' is a discursive product of the post-WWII period and was institutionalised in the second half of the twentieth century. Most of what we read and hear about development, including the SDGs, its targets and indicators, rest on the assumptions of mainstream economic thinking, outlined by Haddad (2012): economic growth leads to poverty reduction, economics is the dominant discipline in policy discourse, the West needs to drive international development, and that international development evidence base is becoming stronger. These assumptions also underpin key writing on the SDGs such as Sachs et al. (2019). When applied to higher education, the mainstream thinking perpetuates what Chankseliani et al. in this special issue refer to as the essentialist orthodoxy of development, which promotes the advancement of human capital and the modernisation of societies. According to human capital theory, there is a causal link between investment in education and development. This link is normally demonstrated by using econometric methods to calculate rates of return on investment in education. Numerous studies show that higher 
education improves the skills and knowledge base, through teaching and research, and this leads to economic development (Bloom et al. 2014; Oketch et al. 2014; Teixeira \& Queirós 2016).

Modernisation theory promotes the idea of building modern as opposed to traditional values, and higher education has been seen to aid modernization of societies (Brennan et al. 2004; Rungfamai 2019). The SDGs, and the literature on achieving them (Sachs et al. 2019), build on the dominant essentialist orthodoxy of development and expand it to include the social, environmental and health-related goals that go beyond the immediate economic understanding of development. Viewing the contributions of higher education within the limits of the essentialist orthodoxy and/or working within higher education with the orthodox assumptions of human capital and modernization can impede the achievement of the three overarching aims of the SDGs: ending extreme poverty, fighting inequality and injustice, and fixing climate change. Walter Mignolo offers an example that can be illuminating for our argument. He writes about a discipline in Mexico called pobretología (povertology) which:

provides information about the poor and by so doing, also provides the illusion that something is being done. But the forward-looking research focuses on progress, development, and growth, all initiatives that on the one hand generated poverty and on the other maintain and increase it. (Mignolo 2012, p. 5).

Overcoming of the mainstream frame of mind about development, and higher education's contributions to development, requires a sufficiently expansive vision and a broader understanding that encompasses the rights-based, capabilities, and liberation approaches to development. When applied to education, the rights-based approach views it as a universal human right that should be guaranteed to all, while the capabilities approach focuses on how higher education expands individuals' freedoms to pursue what they value (Boni \& Walker 2016; McCowan 2013). According to these approaches, higher education is far more than a tool to acquire skills, knowledge, and credentials. Universities allow individuals to pursue freedoms that they value and that they have rights to pursue, and to develop their agency freedom, irrespective of social class, ethnicity and gender, leading ultimately to holistic human development. The liberation approach (Freire 1972) is yet another way to view the role of higher education in development, and this is linked closely with human capabilities. Thus, development can be seen in ways different from the essentialist orthodoxy. Adopting this expansive view shows higher education in a different light—as a powerful space that can help individuals realise their human rights and capabilities to pursue the freedoms that they value, to liberate their minds and bodies, leading to the liberation of entire societies. Our framing of the role of higher education for development needs to go beyond the dominant development orthodoxy and advance a more nuanced and holistic understanding of university education, research and engagement.

Going beyond the dominant orthodoxy would involve defining 'development' as encompassing issues of identities, values, freedoms, social change, liberation, and agency of individuals, institutions and societies to chart their own paths for development. Multiple papers included in this issue are implicitly or explicitly concerned with these issues. Yet, there exists a great variation in the capacity of higher education institutions to imagine, design, implement, and promote the links between universities and development for the purpose of achieving social change, understood broadly.

This special issue addresses these empirical and normative questions. The international, interdisciplinary contributions to the special issue engage critically with two disparate assumptions emerging from different strands of the recent discourses on the SDGs. First, 
the SDGs provide a framework that allows the international development community to promote and fund initiatives to achieve sustainable development. Second, the SDGs do not fully reflect locally valued, indigenous meanings pertaining to the challenges and the ways of addressing these, in different international contexts.

The papers in this special issue explore the important but empirically elusive link between higher education and (inter)national development by building on the literature in global higher education as well as the evidence from across Africa, Latin America and Asia. Most evidence included in the issue pertains to low- and middle-income countries, such as Georgia, Ghana, Iran, Kazakhstan, Mexico, Nigeria, Philippines and Turkey. Two of these contributions use multi-country evidence. Sansom Milton looks at conflictaffected settings in Afghanistan, Syria, Yemen, South Sudan, Somalia and the Gaza Strip. Meggan Madden and Amy Jamison examine experiences of individuals from Kenya, Malawi, Rwanda, Senegal, Somalia, Tanzania and Uganda. The experiences of locals are linked with the global framework to ultimately let the reader undertake an unconventional analysis of changing perspectives-viewing the global from the perspective of the local and viewing the local from the perspective of the global. In other words, the authors examine local issues and models using the global SDG lens and the global literature. At the same time, authors provide their own take on the SDGs emerging from the local embeddedness of their cases.

Though by no means exhaustive of all that can be written about higher education and the SDGs, the papers included in this special issue collectively:

(a) add to the evidence on and conceptualisation of higher education's potential of contributing to the SDGs;

(b) explore the extent to which the SDGs can provide a concise and clear framework for explaining the contributions of higher education or alternatively restrict our understanding of the role of higher education for development;

(c) assess ways in which contemporary higher education may fulfil its educational, research and engagement functions that ultimately lead to the SDGs while not being explicitly driven by the SDG framework; and

(d) analyse the factors facilitating or constraining universities' contribution to the SDGs, in terms of societal dynamics, global trends and higher education policy.

The contributors offer analysis of how higher education can respond to the global challenges related to gender equality and empowerment of women; promotion of peaceful, inclusive societies and access to justice and building effective, accountable and inclusive institutions; eliminating extreme poverty; ending hunger; supporting inclusive and sustainable economic growth, full and productive employment and decent work. The papers by Lavinia Hirsu, Zenaida Quezada-Reyes and Lamiah Hashemi and Melis Cin, Sedat Gümüş and Felix Weiss link higher education with gender equality and empowerment of women (SDG5). Hirsu et al. investigate female academics' aspirations, opportunities and experiences of public engagement in Iran and Philippines to show that patriarchal structures and distrust in women's expertise impede the public engagement of female academics. The authors develop a number of recommendations aimed at improving the necessary support structures for female academics. Cin et al. approach SDG5 from a different perspective. They examine the statistics of the higher education attainment of females in the Turkish context and link these with the labour force participation, gender segregation in employment, and the gender pay gap. Cin et al. show that despite deeply-rooted gender inequalities 
across all sectors in Turkey, higher education expansion has contributed to the equalisation of labour market outcomes by gender.

Achieving gender equality in enrolments is an important outcome of the Intercultural University of Veracruz in Mexico which enables access for marginalised populations and contributes to environmental protection, health and livelihoods, among other important sustainable development outcomes. The contribution by Cristina Perales Franco and Tristan McCowan examines the case of this university which ensures access for indigenous populations and promotes intercultural dialogue. This institution is characterised by a high degree of integration between teaching, research and community engagement. Communitybased research is a central aspect of learning in undergraduate courses, and academics are actively engaged in community work. The paper argues that strong links between universities and their local communities can be transformative for societal development. The paper raises concern about the possibilities of having similar institutional models within the mainstream higher education institutions which are normally either research-intensive or demand-absorbing.

The promotion of peaceful, inclusive societies and access to justice and building effective, accountable and inclusive institutions (SDG 16) is the central theme of Sansom Milton's paper which looks at higher education in fragile and conflict-affected contexts. The paper presents examples of how universities work towards promoting peaceful, just and inclusive societies. At the same time, it raises concerns regarding the potential risks of limiting engagement to technical support within donor-driven projects. Academic freedom is fragile in conflict-affected areas. The need to make political compromises can interfere with researchers' critical engagement which is central for any work towards SDG 16.

Academic freedom emerges as a central concept in the paper by Maia Chankseliani, Ikboljon Qoraboyev and Dilbar Gimranova. This study presents Georgian and Kazakhstani academics' insights on how higher education can help achieve and exceed the SDGs, including but not limited to eliminating extreme poverty (SDG 1), ending hunger (SDG 2), supporting inclusive and sustainable economic growth, full and productive employment and decent work (SDG 8). The study offers evidence on the national manifestations of the developmental role of universities. Yet, it shows that limited academic freedom and institutional autonomy impede the full realisation of the potential of higher education. Juxtaposing the national with the global development missions of universities, the paper raises questions on the possibility of delinking higher education from the immediate human capital and modernisation needs of the nation-state and becoming concerned with the global, on promoting freedom to cultivate intellectual curiosity through education and research, and stimulating a more holistic imaginary of the developmental purposes of higher education.

Two studies in this special issue-by Anne Campbell, Erin Kelly-Weber and Chelsea Lavallee and by Meggan Madden and Amy Jamison-go beyond the human capital framework and present evidence on broader contributions of international higher education. Both of these studies explore the experiences of African alumni of American universities. Campbell et al. find that scholarship alumni from Ghana and Nigeria contribute to social change back at home through university teaching and through citizenship, voter and human rights education. Madden and Jamison's paper examines social and civic engagement experiences of alumni to see how these can be linked with their higher education experiences. The findings indicate that the majority of participants report more social and civic engagement post-graduation.

In addition to examining these positive potentialities of universities, the special issue addresses some of the more intractable questions. To what extent are higher education institutions and systems equipped to take on this new role, in fostering inclusive societies, 
addressing global challenges and responding to crises? And is the vision of higher education inclusive of all communities, their epistemologies, values and the meanings attached to education? Can an institution that has historically functioned to reproduce elites, work to combat the roots of structural and cultural violence? The papers highlight the importance of sustained efforts for higher education capacity building in the Global South (Heleta and Moodien), local institutional innovation (Perales Franco and McCowan) and academic freedom and institutional autonomy (Chankseliani et al.) for the full realization of the developmental mission of higher education.

Savo Heleta and Tohiera Bagus contend that the SDGs' neglect of higher education will leave many behind in low-income countries. The paper argues that resources currently channelled into scholarships for the citizens of these countries to study abroad need to be redirected to the (re)building of universities and the fragile systems of higher education. The current patterns of international financing of higher education in low-income countries perpetuate the dependency on financial aid. Instead, the aid needs to be spent on higher education capacity-building in these countries. Only through a substantive reform of higher education will low income countries be able to deliver quality education that will lead to sustainable development.

Finally, Elaine Unterhalter and Coleen Howell's contribution offers a rigorous review of existing literature on the role of tertiary education in low- and lower-middle income countries. The authors find that there exists a limited number of studies that link tertiary education with development outcomes. A considerable portion of these studies indicates that there is a mismatch between tertiary education and development outcomes, and that tertiary education in many of the low- and lower-middle income countries is not in a position to support the implementation of the SDGs. This paper also argues that partnerships and alliances across institutions can lead to potentially useful enhancement of practices of joint learning for addressing SDGs.

It might be surprising to some of our readers that the articles collected here do not focus more on questions of the natural environment, climate change, conservation and the ecosystem. Indeed, 'sustainability' is often taken to refer predominantly to these environmental questions. The focus on human dimensions is a result of the proposals that were forthcoming for the special issue, and not an indication of our conceptual framework of sustainable development, which includes the natural environment as an essential part. A number of the contributions to this issue do indirectly address the capacity of universities to contribute to solving environmental challenges such as climate change, and see these questions as inseparable from those of global social justice.

It is important to acknowledge that contemporary higher education in various global contexts does not appear to draw on the SDGs explicitly. Instead, the papers indicate that higher education has been performing its three core functions of education, research and engagement long before the global community agreed on the SDGs and, while government documents may refer to SDGs as benchmarks, the global goals do not in all cases explicitly drive higher education policy and practice. A significant question for further exploration concerns the extent to which explicit alignment influences university activities in practice.

The ongoing COVID-19 pandemic that has led to a global human and socioeconomic crisis makes the developmental role of universities more visible. While the United Nations' latest Sustainable Development Goals Report does not mention higher education (United Nations 2020), in the course of 2020, some of the world's leading universities have been at the forefront of developing drugs against the virus and vaccine to protect humanity from the virus, researching and reporting on the societal impact of the pandemic, and advising governments on the ways of recovering from the crisis. At the same time, universities have 
continued performing their educational mission, despite the significant challenges of rapidly moving their courses online. Yet, the pandemic is imperilling the progress towards the 2030 agenda (United Nations 2020) and may place significant constraints on the activities of higher education institutions, not only due to their forced closure, but also because of the looming financial risks and cuts to their resources.

The pandemic notwithstanding, there are a series of ongoing factors constraining the ability of universities to contribute to the development of their societies, affecting what Unterhalter et al. (2018) call the conditions of possibility. Many countries lack the resources to fund higher education systems that can offer a minimum level of quality for their populations, or prioritise other areas of government expenditure. Even in resourcerich contexts, there are global dynamics that act against the promotion of the public good (Marginson 2011), including privatisation of public sectors, growth of for-profit institutions and pressures of international rankings to prioritise elite research over local engagements. Many universities and staff working within them are strongly committed to sustainable development but encounter an increasingly compressed space in which to contribute to it. While the pandemic has been exacerbating these constraints, it can also offer a unique opportunity to reimagine higher education as a common good. The understanding of higher education as a common good carries the promise of reinforcing the humanistic vision of higher education that is collectively produced and shared and that contributes to just, equitable, and sustainable development (Brotherhood et al. 2020; Locatelli 2018; Marginson 2016; UNESCO 2015). Higher education as a common good builds on the values that we collectively share, such as social justice and solidarity, and offers a promising vision for the future, post-pandemic higher education.

\section{References}

Aarts, H., Greijn, H., Mohamedbhai, G., \& Jowi, J. O. (2020). The SDGs and African higher education. In M. Ramutsindela \& D. Mickler (Eds.), Africa and the Sustainable Development Goals (pp. 231-242). Springer International Publishing. https://doi.org/10.1007/978-3-030-14857-7

Bloom, D. E., Canning, D., Chan, K. J., \& Luca, D. L. (2014). Higher Education and Economic Growth in Africa (SSRN Scholarly Paper No. ID 2540166). Rochester, NY: Social Science Research Network. https://papers.ssrn.com/abstract=2540166. Accessed 25 October 2019

Boni, A., \& Walker, M. (2016). Universities and Global Human Development: Theoretical and empirical insights for social change. London: Routledge.

Brennan, J., King, R., \& Lebeau, Y. (2004). The role of universities in the transformation of societies: an international research project: synthesis report. London: Association of Commonwealth Universities and the Centre for Higher Education Research and Information. https://eclass.upatras.gr/modules/ document/file.php/PDE1516/universities\%20transformation\%20societies.pdf. Accessed 16 June 2020

Brotherhood, T., Yang, L., \& Chankseliani, M. (2020, September 10). COVID-19 and higher education: Implications for equity, and a return to the common good. The post-pandemic university. https:// postpandemicuniversity.net/2020/09/10/covid-19-and-higher-education-implications-for-equity-and-areturn-to-the-common-good/. Accessed 12 September 2020

Castells, M. (1994). The university system: Engine of development in the new world economy. In J. Salmi \& A. M. Verspoor (Eds.), Revitalising higher education (pp. 14-40). Oxford: Pergamon. https://collections. infocollections.org/ukedu/en/d/Jwb20ie/6.html

Freire, P. (1972). Pedagogy of the oppressed. New York: Herder and Herder.

Haddad, L. (2012). Five assumptions of dominant thinking in international development. Development, 55(1), 34-44. https://doi.org/10.1057/dev.2011.106

Locatelli, R. (2018). Education as a public and common good: reframing the governance of education in a changing context - UNESCO Digital Library. UNESCO. https://unesdoc.unesco.org/ark:/48223/ pf0000261614. Accessed 7 September 2020 
Marginson, S. (2011). Higher education and public good. Higher Education Quarterly, 65(4), 411-433. https://doi.org/10.1111/j.1468-2273.2011.00496.x

Marginson, S. (2016). Higher Education and the Common Good. Carlton, Vic: Melbourne University Press.

McCowan, T. (2013). Education as a human right: principles for a universal entitlement to learning. London: Bloomsbury Academic. https://ezproxy-prd.bodleian.ox.ac.uk/login?url=https://doi. org/10.5040/9781472552938?locatt=label:secondary_bloomsburyCollections. Accessed 17 September 2020

McCowan, T. (2016). Universities and the post-2015 development agenda: an analytical framework. Higher Education, 72(4), 505-523.

McCowan, T. (2019). Higher Education for and beyond the Sustainable Development Goals. Cham, Switzerland: Palgrave Macmillan.

Mignolo, W. (2012). Globalization and the Geopolitics of Knowledge: The Role of the Humanities in the Corporate University. In K. L. Kleypas \& J. I. McDougall (Eds.), The American-Style University at Large: Transplants, Outposts, and the Globalization of Higher Education (Vol. 4, pp. 3-39).

Milton, S., \& Barakat, S. (2016). Higher education as the catalyst of recovery in conflict-affected societies. Globalisation, Societies and Education, 14(3), 403-421. https://doi.org/10.1080/14767724. 2015.1127749

Neave, G. R., International Association of Universities, \& Mid Term Conference of Heads of Universities. (2000). The universities' responsibilities to society: international perspectives (1st ed.). Amsterdam: Pergamon, published for the IAU Press.

Oketch, M., McCowan, T., \& Schendel, R. (2014). The Impact of Tertiary education on development: A rigorous literature review. London: DFID.

Owens, T. L. (2017). Higher education in the sustainable development goals framework. European Journal of Education, 52(4), 414-420.

Rungfamai, K. (2019). State, university, and society: higher educational development and university functions in shaping modern Thailand. Higher Education, 78(1), 149-164. https://doi.org/10.1007/s10734018-0335-1

Sachs, J. D., Schmidt-Traub, G., Mazzucato, M., Messner, D., Nakicenovic, N., \& Rockström, J. (2019). Six Transformations to achieve the Sustainable Development Goals. Nature Sustainability. https://doi. org/10.1038/s41893-019-0352-9

Schendel, R., \& McCowan, T. (2015). Higher Education and Development: Critical Issues and Debates. In T. McCowan \& E. Unterhalter (Eds.), Education and development: An introduction (pp. 275-294). London: Bloomsbury Academic. Accessed 22 March 2019

Teixeira, A. A. C., \& Queirós, A. S. S. (2016). Economic growth, human capital and structural change: A dynamic panel data analysis. Research Policy, 45(8), 1636-1648. https://doi.org/10.1016/j.respol. 2016.04.006

THE. (2020). Impact Rankings 2020. https://www.timeshighereducation.com/rankings/impact/2020/overa 1l\#!/page/0/length/25/sort_by/rank/sort_order/asc/cols/undefined. Accessed 25 May 2019

UNESCO. (2015). Rethinking education: Towards a global common good. Paris: UNESCO.

United Nations. (2018). SDG Hubs. https://academicimpact.un.org/content/sdg-hubs. Accessed 26 February 2019

United Nations. (2020). The Sustainable Development Goals Report 2020. New York: United Nations. https:// unstats.un.org/sdgs/report/2020/. Accessed 25 October 2020

Unterhalter, E., Allais, S., Howell, C., McCowan, T., Morley, L., Ibrahim, O., \& Oketch, M. (2018). Conceptualising Higher Education and the Public Good in Ghana, Kenya, Nigeria, and South Africa. Presented at the CIES 2018 Annual Conference, Mexico City, Mexico.

Publisher's Note Springer Nature remains neutral with regard to jurisdictional claims in published maps and institutional affiliations. 